IRSH 46 (200I), pp. 34I-369 DOI: I0.1017/S0020859001000232

(C) 200 I Internationaal Instituut voor Sociale Geschiedenis

\title{
Labour Politics in a Naval Dockyard: The Case of Karlskrona, Sweden c. I880-1925*
}

\author{
MARY HILSON
}

Summary: Naval dockyards have been largely neglected by labour historians, a surprising omission given their importance as industrial workplaces with a distinct culture of labour and labour relations. This article considers labour politics in Karlskrona dockyard, Sweden, in the light of a growing body of research on work and labour relations in the British and other European dockyards. Evidence from Karlskrona suggests that, rather than being repressed by military discipline or bought off by generous state benefits, the dockyard workforce drew on aspects of its unique relationship with the national state to improve working conditions. Particular attention is given to the role of the dockyard trade union in creating a sense of workforce identity as state employees. This is in contrast to the British dockyards where unionism was founded on the rigid division of labour in the shipbuilding industry.

\section{INTRODUCTION}

Naval dockyards ${ }^{\mathrm{I}}$ seem to have represented a dilemma for the organized European labour movement during its formative years. The situation of dockyard workforces was ambivalent, nominally civilian but often subject to military methods of organization and control, whilst employment within the defence industry itself represented a profound conflict of interest to a movement committed to internationalism. Consequently, these workers have often been omitted from historical studies of late nineteenth-century and early twentieth-century labour, and where they have been studied, labour historians have tended to take for granted the tardiness of the rise of labour in dockyard towns. As Kenneth Lunn puts it,

\footnotetext{
* An earlier version of this article was delivered to the European Social Science History Conference, Amsterdam, April 2000. I am grateful to all who took part for their comments, and especially Ken Lunn, Ann Day, and Alex Law. The research for this article was supported by a Study Abroad Studentship from the Leverhulme Trust. I would also like to thank staff at the Marinmuseum, Karlskrona, for their helpfulness.

I. A word on terminology: the term dockyard is used here in its British sense to denote a shipyard directly owned and managed by the state for the construction and maintenance of naval warships. Not all languages make this distinction between naval dockyard and private shipyard; in Swedish for example the word varv covers both types of organization.
} 
writing of the British dockyard towns, "It has become almost an historical cliché to link [...] naval history with a retardation of the labour movement in these areas." ${ }^{2}$ Another British labour historian has described the Conservative Party as the "natural party" of southern ports such as Portsmouth, Plymouth, and Chatham. Secure employment, the lack of any tradition of hostility to authority, and passive acceptance of Conservative "big navy" politics meant that in these areas there was "little reason to support Progressive parties, with their commitment to state intervention, and traditional hostility to the military and military expenditure". ${ }^{3}$

The assumption of a direct relationship between the dockyard towns and support for naval imperialism is not always borne out by the available evidence, however. There were other aspects to dockyard employment which need also to be taken into account. Most European naval dockyards were precociously large industrial establishments with exceptionally longestablished practices and traditions. Many had been in continuous operation for over 200 years by this period. Moreover, although dockyard workforces were sheltered from the fluctuations of the capitalist business cycle, they were subject instead to different constraints, related to foreign policy and military strategy, and this could present both opportunities and difficulties for political parties trying to formulate a strategy for statecentred reform. A growing body of research on the British dockyards now points towards a considerably more complex model of dockyard labour, which shows that far from being "bought out" by naval imperialism, or repressed by military discipline, dockyard workers made creative use of the resources available to them to challenge aspects of their working conditions. ${ }^{4}$ Furthermore, dockyard labour relations and labour cultures were never static, but were constantly reformed in response to changes both within the dockyards and without.

The present article draws closely on this British work to consider the case of Karlskrona dockyard in Sweden. Karlskrona has been largely neglected by Swedish labour historians, and, typically of dockyard histories, more attention has been paid to celebrating the ships than the

2. Kenneth Lunn, "Labour Culture in Dockyard Towns: A Study of Portsmouth, Plymouth and Chatham, I900-1950", Tijdschrift voor Sociale Geschiednis, I 8 (1992), pp. 275-293, 275.

3. Duncan Tanner, Political Change and the Labour Party, I900-I9I8 (Cambridge, 1990), p. 190. Similar assumptions have also been made about France, where "dependence on the state generally assured the triumph of reformist politics in naval shipyard towns"; Donald Reid, "The Third Republic as Manager: Labor Policy in the Naval Shipyards, 1892-1902", International Review of Social History, 30 (1985) pp. I 83-206, 202. See also Jean Quellien, "Un milieu ouvrier réformiste: syndicalisme et réformisme à Cherbourg à la 'Belle Époque', Mouvement Social, I 27 (1984), pp. $65-88$.

4. See in particular the essays in Kenneth Lunn and Ann Day (eds), History of Work and Labour Relations in the Royal Dockyards (London, 1999). Also M.K. Hilson, "Working-class Politics in Plymouth, c.1890-1920” (Ph.D., University of Exeter, I998). 
men and women who built them. ${ }^{5}$ Like the British dockyards, Karlskrona was owned and directly managed by the state, but as we shall see, it differed crucially in several important respects. This article attempts to establish what common factors, if any, distinguished work and labour relations in Karlskrona as belonging to a state-owned dockyard, and the extent to which this influenced the development of a particular model of labour politics in the town during the crucial years of the rise of labour. Particular attention is paid to the role of the dockyard trade union in creating a collective consciousness among the dockyard workers of their status as state employees.

\section{KARLSKRONA AND THE DOCKYARD}

Founded by King Karl XI in I680, the Swedish naval dockyard town of Karlskrona was intended to replace Stockholm as the main base for the Swedish navy, at that time engaged in defending an extensive Baltic empire. The location of the new town in the southeastern province of Blekinge was part of a strategy to fend off Danish claims to the southern part of Sweden. Furthermore, unlike Stockholm, it was located far enough south for the harbour to remain ice-free throughout the winter. ${ }^{6}$ The removal of the entire Swedish navy, and the thousands of personnel connected with it, was an immense project which amply indicates the extent of the power and resources the Swedish state had at its disposal at this time. Karlskrona itself, with its carefully planned layout and imposing public buildings, may be seen as a monument to Swedish imperial ambitions at their height. The implications of this relocation were twofold. Firstly, Karlskrona grew rapidly from its foundation to become the third largest town in Sweden by the second half of the eighteenth century, with what was almost certainly one of the largest industrial workplaces. The Blekinge hinterland remained centred on agriculture, however, despite the development of a quarrying and stonemasonry industry, based around the neighbouring port of Karlshamn. By the end of the nineteenth century, therefore, it is clear that Karlskrona presents a case of extreme geographical isolation from the major industrial and commercial districts, and not least from the west-coast ports and engineering centres of Göteborg and Malmö. This made the town vulnerable to any contraction of the dockyard, and also had implications for the local labour market.

That Karlskrona itself was an important industrial centre cannot be doubted, and, like most other dockyards, the town could, furthermore,

5. A welcome and important exception to this tradition is the comprehensive work by Erik Norberg (ed.), Karlskrona varvets historia, 2 vols (Karlskrona, 1993).

6. For the foundation and early history of Karlskrona, see Lars Ericson, "Pionjärer och rustningar 1680-1721", in Norberg, Karlskrona varvets historia, vol. I. 


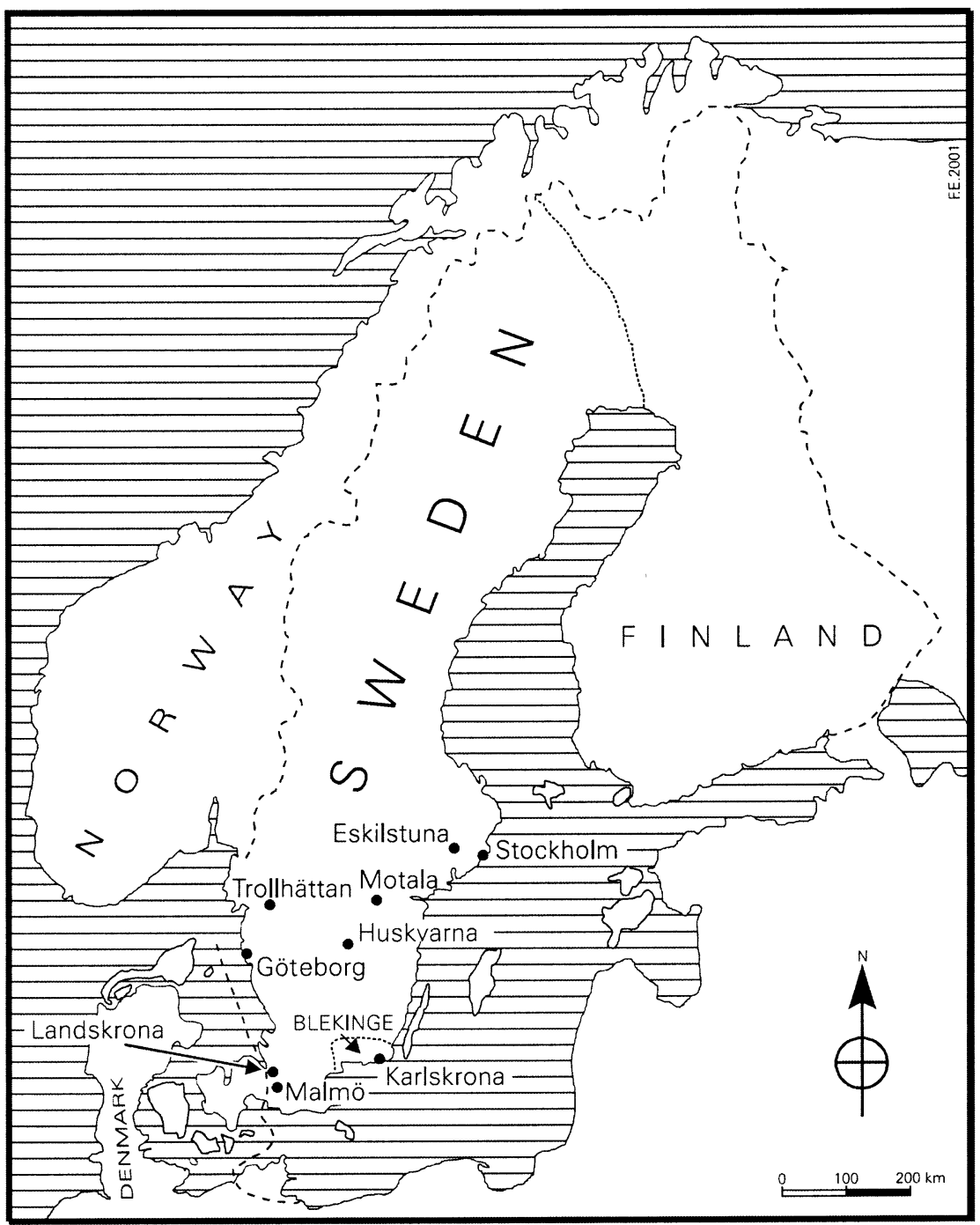

Figure I. Karlskrona, the Baltic, and some major Swedish industrial towns, c.1900.

demonstrate a unique degree of continuity. By the late nineteenth century this was an enterprise which had been in continuous operation for over 200 years, and thus stood in contrast to the traditional portrayal of Sweden as a backward, agrarian economy which industrialized only from the second half of the nineteenth century. ${ }^{7}$ Yet the late nineteenth century was also a

7. See Eli F. Hecksher, An Economic History of Sweden, transl. Göran Ohlin (Cambridge, MA, I954). 
Table I. Industrial workforce in Sweden's largest industrial districts, c. 1900

\begin{tabular}{lcc}
\hline District & Number of workers & Number of businesses \\
\hline Stockholm & 5,419 & 24 \\
Göteborg & 2,330 & 13 \\
Eskilstuna & 1,328 & 4 \\
Malmö & 1,25 & 2 \\
Motala & 1,013 & 1 \\
Huskvarna & 1,010 & 1 \\
Trollhättan & 840 & 1 \\
Karlskrona dockyard & 1,371 & $(1)$ \\
Whole country & 23,207 & 138 \\
\hline
\end{tabular}

Source: Thommy Svensson, Från ackord till månadslön. En studie av lönepolitiken, fackföreningarna och rationaliseringarna inom svensk varvsindustri under 1900-talet (Kungälv, I983) p. 25. KrA, KÖV Varvschefens militärexp, serie Di, vols 8-9, Journal över Uppgifter beträffande Varfsdriften, I 898-I910.10

period of great change for Karlskrona. By the I860s, with the advent of iron and steel shipbuilding, it was becoming apparent that extensive modernization was necessary if the dockyard were to continue to serve a useful role. The construction of new workshops, a new railway system and new docks in the I880s created the necessary infrastructure for the production of modern steel battleships, although the dockyard never developed the capacity to take on the very large vessels of the immediate prewar era. Indeed, from the late nineteenth century, new construction began increasingly to be contracted out to private firms, leaving the state dockyard to concern itself principally with the maintenance, repair, and fitting out of the fleet. ${ }^{8}$ Despite this redefinition of its role, Karlskrona dockyard nonetheless remained one of Sweden's largest industrial workplaces during this period. The commercial shipbuilding industry in Sweden was also concerned mainly with repairs during the period before I920, and the three largest shipyards in Göteborg employed between 500 and I,000 workers before I 91 $4 .{ }^{9}$ This compares with a peak of over 2,000 for Karlskrona in 1904. A fuller comparison is presented in Table I.

8. Ann Hörsell, "Från segel och trä till ånga och stål ı866-ı19", and Björn Gäfvert, "Kontinuitet i föränderlig omvärld I910-1945"; both in Norberg, Karlskrona varvets historia, vol. 2.

9. For the shipbuilding industry in Sweden see Jan Bohlin, Svensk varvsindustri 1920-1975. Lönsambet, finansiering och arbetsmarknad (Göteborg, 1989); Bo Stråth, Varvsarbetare $i$ två varvstäder. En historisk studie av verkstadsklubbarna vid varven $i$ Göteborg och Malmö (Göteborg, 1982).

I0. Svensson points out that the dockyard workers at Karlskrona and Stockholm were not included in the survey as they were reckoned as naval personnel, and not industrial workers. However, as will be shown, the proportion of civilian workers in the yard was increasing steadily during this period, and there seems to be no reason why these should not be included. 


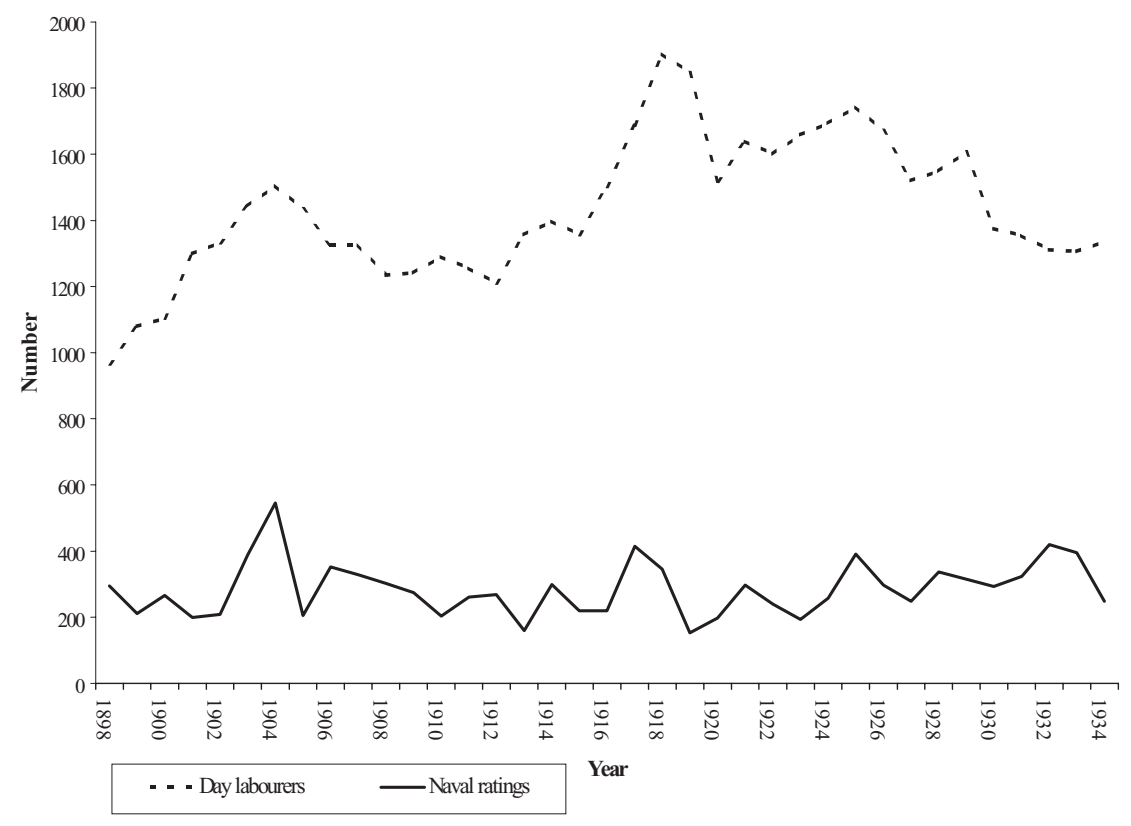

Figure 2. Karlskrona dockyard civilian and naval workforce, I 898-1934 Source: Krigsarkivet, Karlskrona Örlogsvarvet, Varvschefens militärexpedition, Serie Dr: vols 8 9, Journal över Uppgifter beträffande Varfsdriften, I 898- I9 Io; vols 9-I I, Journaler I 9 I I - I 939.

Characteristically of naval dockyard towns, the development of Karlskrona was governed by political and strategic decisions taken at the level of the national state, and thus was intimately connected with the needs of foreign and defence policy. ${ }^{\text {I }}$ By the mid-nineteenth century, the dockyard had outlived Sweden's great power status, and its role had to be adapted to serve the defence interests of a minor, relatively poor, European nation which based its foreign policy on nonalignment and neutrality. ${ }^{\mathrm{I}}$ Following the defeat of Germany in 1918, and the retreat of the Russian threat, economy in military spending became a political priority, and this was duly reflected in the sharp contraction in the dockyard workforce between 1918-1920, illustrated in Figure 2. The local authorities sent a deputation to Stockholm to lobby the government, and a number of official enquiries considered the possibility of turning the dockyard's spare

I I. See Trevor Harris, "Government and the Specialised Military Town: The Impact of Defence Policy on Urban Social Structure in the Nineteenth Century", in Michael Bateman and Raymond Riley (eds), The Geography of Defence (London, 1987), pp. 100-140.

I2. For late nineteenth-century Swedish defence policy, see Hans Holmén, Försvar och sambällsförändring: Avvägningsfrågor i svensk försvarsdebatt I880-I925 (Gothenburg, I985). 
capacity over to civilian uses, such as the construction of railway carriages, or the repair and maintenance of merchant vessels. In fact, the dockyard workforce recovered fairly quickly after the postwar contraction, but the episode indicates just how dependent the town was on the decisions of metropolitan government. The town council lobbied hard, and provided evidence to suggest that between $4 \mathrm{I}$ and 42 per cent of Karlskrona's population were connected with the local military institutions in some way. ${ }^{13}$

\section{ORGANIZATION OF THE DOCKYARD AND THE DIVISION OF LABOUR}

The organization of naval dockyards was always rather ambivalent: neither military nor civilian, and Karlskrona was no exception in this respect. Dockyard production was organized through a highly centralized, bureaucratic system which relied primarily on military chains of command. The head of the dockyard, or varuschefen, was of military rank equivalent to a commodore (kommendör), responsible to the Royal Naval Administration (Kungliga Marinförvaltningen or KMF), and in military matters to the local commander-in-chief (Stationsbefälhavaren för Karlskrona station). ${ }^{14}$ Ultimate authority over the dockyard's work rested, therefore, with the metropolitan state machinery, exercised through the KMF and the government's naval minister (sjöminister). Decisions concerning the work to be undertaken by the yard were made in Stockholm; decisions concerning the planning and organization of this work were the responsibility of the varuschef and the officers in charge of the various dockyard departments. Where Karlskrona differed from the British dockyards, however, was that military structures permeated beyond the level of senior management right through the workforce. Whilst naval officers of various ranks were employed in supervisory roles, men from the lower deck provided general unskilled labour, performing such tasks as transporting materials, loading and unloading ships, and acting as guards and porters on the dockyard gates. These men worked alongside a civilian workforce of day-labourers, who carried out the skilled and semiskilled shipbuilding work. From the i 860s, the use of naval personnel in dockyard work was strongly criticized by a number of inquiries, which argued that their employment for civilian tasks was an inefficient use of resources, and, furthermore, did not help to create good seamen. ${ }^{\text {Is }}$ The dockyard workforce was to be gradually civilianized. In

I 3. Rune Hillbom, Karlskrona 300 år, del 2, I870-I930, p. I0. As Hillbom puts it (p.4), "I alla tider har försvarsfrågan för Karlskrona framstått som en fråga om en dräglig framtid.”

I4. Gäfvert, "Kontinuitet i föränderlig omvärld", pp. 8I-202, 106-I07.

I 5 . Hörsell, "Från segel och trä”, p. 68. 
I 868, naval ratings made up over 58 per cent of the total workforce, excluding supervisory officials and officers, and prisoners. ${ }^{16}$ By the turn of the century, however, they were reduced to just over I 6 per cent of the total, as shown in Figure 2. The diagram also illustrates the impact of military crisis, notably the Norwegian secession from Sweden in I905, which temporarily drained the yard of its naval workers as these were ordered to sea.

The status of the day labourers, with which this article is mainly concerned, was ambiguous, neither military nor truly civilian. Under the naval regulations, both day labourers (dagslönare), and their nonmilitary supervisors (manadslönare), were allotted a special noncombatant military status, with ranks equivalent to that of ordinary seamen and noncommissioned officers respectively. ${ }^{17}$ This meant that day labourers were bound, under the terms of their contract, to accept naval regulations, and could, in theory, face military punishments for infringement of these regulations. ${ }^{18}$ Although there is no evidence of an outright ban on trade unions, it is quite clear that there were factors which could work against trade unionism amongst the day labourers, and there is no evidence for the existence of a workers' organization before 1900. Moreover, during the early twentieth century, the dockyard workforce still included a considerable proportion of military workers, for whom trade organizations were simply not a proposition. As far as the day labourers were concerned, the regulations proscribed the employment of anyone likely to "disrupt the harmony between supervisors and workers", and forbade the circulation of any kind of printed matter among the dockyard workforce, a measure which seems expressly designed to hinder collective organization. Nor was it officially allowed to collect money during working hours, or even to engage in "unnecessary" conversation, although it is not clear to what extent these formal provisions were enforced in practice. ${ }^{19}$ It is not certain either that these restrictions were any more severe than those experienced by workers in private industry during the same period, but the conventional wisdom is

I6. This last category was also a declining group within the yard. Prisoners had been used within the yard since the seventeenth century for performing heavier manual work, such as in the anchor smithy, and they were later used for other types of work including coaling and cleaning. Fifty-three prisoners were employed in the dockyard in 1868 , but the use of penal labour was phased out by the beginning of the twentieth century.

I7. Krigsarkivet, Stockholm [hereafter KA], Reglemente för Marinen, del I (I9Is edition), Kap I, §I 4, I 5 .

I8. KA, Reglemente för Marinen, del I (1907 edition), ' 57:2.

I9. KA, Reglemente för Marinen, del I (1915), Bil 46, "Bestämmelser för varvsarbetare vid flottan”, §I:I; §4:2. 
that the military oppression of the workforce accounted for the tardiness of a trade union movement in the dockyard. ${ }^{20}$

British research has challenged assumptions about the quiescence of dockyard workforces, and suggests instead a dynamic model of dockyard labour relations which was constantly evolving in response to a number of factors operating both within and without the yards. As Roger Knight and Roger Morriss have shown, the late eighteenth century, in particular, was a time of heightened dockyard radicalism, resulting in several long-running strikes and disputes. ${ }^{21}$ This militancy had declined by the nineteenth century, but instead, dockyard workers made fruitful use of longstanding traditions of political lobbying. Rather than signalling a culture of deference and submissiveness, it has been suggested that the creative use of petitions could challenge existing structures of authority, and foreshadowed modern channels of political influence, for example through the dockyard constituency MP. ${ }^{22}$ The unusual availability of direct channels of access to the state is an aspect which appears to characterize dockyard labour relations. Writing of the French dockyards in this same period, Donald Reid suggests that, "For naval shipyard workers the relationship between workplace life and politics was less problematic than for most industrial workers", and it seems that French deputies were equally active on behalf of their dockyard constituents. ${ }^{23}$

Existing structures for the redress of grievances, such as the petitions system, began to come under severe strain towards the end of the nineteenth century, as dockyard workers looked increasingly towards TUC-affiliated trade unions to defend their interests. ${ }^{24}$ Admiralty policy did not explicitly encourage trade unions, but up until the i 880 s, the threat of dismissal from what was effectively a job for life was an effective deterrent against forming a union. The decline of the Establishment system - which maintained a core group of permanent workers with

20. See, for example, the centennial history of the labour movement in Karlskrona, which states that dockyard workers quite simply did not dare to form a union. Karlskrona arbetarekommun, Människor och bändelser - ett axplock: Karlskrona Arbetarekommun I00 år, I896-1996, (Karlskrona, 1996).

2I. Roger Knight, "From Impressment to Task Work: Strikes and Disruption in the Royal Dockyards, I688-1788", in Lunn and Day, History of Work and Labour Relations; and Roger Morriss, "Government and Community: The Changing Context of Labour Relations, I770I 830 ", in ibid., pp. $2 \mathrm{I}-40$.

22. Mavis Waters, "The Dockyardmen Speak Out: Petition and Tradition in Chatham Dockyard, 1860-1906", in ibid., pp. 87-98; idem, "Dockyard and Parliament: A Study of Unskilled Workers in Chatham Yard, I860-1900", Southern History, 6 (1984), pp. I23-I38; Hilson, "Working-class Politics in Plymouth", ch. 2.

23. Reid, "The Third Republic as Manager", p. 192.

24. Peter Galliver, "Trade Unionism in Portsmouth Dockyard, I880-1914: Change and Continuity", in Lunn and Day, History of Work and Labour Relations; Hilson, "Workingclass Politics in Plymouth", ch. 2. 
guaranteed employment and special benefits - and in particular the sharp contraction in the dockyard workforce in 1904-I906 did much to undermine the effectiveness of this deterrent. ${ }^{25}$ The introduction of state pensions and national insurance in the early twentieth century was also influential in that it eroded the dockyardsmen's sense of special privilege. Furthermore, the tightening of the labour market, as the dockyards expanded to cope with prewar armament, probably went some way to undermining the sense of an enclosed dockyard community maintained through generations, introducing new influences through the recruitment of labour from outside. By i9 14, therefore, a large proportion of dockyard workers looked towards the main shipbuilding unions to defend their interests.

As this research illustrates, the system of dockyard labour relations, considered over a longer period, was anything but static, and in this light it is reasonable also to assume a more complicated picture of dockyard labour relations in Karlskrona. Many of the external factors operating in the British case were also present in Karlskrona, not least the tightening of the labour market, and changing assumptions about the continuity of dockyard employment. The trend towards the civilianization of the workforce and the increase in day labourers, and the reorganization of work itself in the wake of technological changes was undoubtedly influential in shaking up established practices within the yard. During the spring of 1900, day labourers founded the Karlskrona Dockyard Workers' Association (Karlskrona Varvsarbetareföreningen or KVAF). In the first flush of enthusiasm the new organization signed up nearly 300 members, but like many labour organizations during this period it struggled for survival, beset by dwindling interest and poorly attended meetings, together with the difficulties of finding a suitable venue to hold its functions, and of persuading members to maintain their monthly contributions. Table 2 illustrates the fluctuating membership from the organization's foundation.

The KVAF seems to have been foremost a social club, which concentrated its efforts on organizing outings, treats, and teas for members and their families, as well as a sports club and a music group. We should, however, be wary of claims that the association was entirely uninterested in campaigning, or unable to mount a challenge to any aspect of prevailing labour relations and conditions. Unlike their British or French counterparts at this time, Karlskrona dockyard workers had no formal channels of redress such as the petitions system, but, despite the lack of official framework, the association made some attempts to open communication

25. For example, nearly 2,500 workers (out of a total workforce of nearly 9,500 in 1903) were discharged from Devonport dockyard during this two-year period. Hilson, "Working-class Politics in Plymouth", p. 38. See also Galliver, "Trade Unionism in Portsmouth Dockyard". 
Table 2. KVAF membership, I900-I9I3

\begin{tabular}{|c|c|c|c|c|}
\hline Year & $\begin{array}{c}\text { Members on } 31 \\
\text { December }\end{array}$ & $\begin{array}{l}\text { Numbers joined } \\
\text { during year }\end{array}$ & $\begin{array}{l}\text { Number not } \\
\text { paid }\end{array}$ & \\
\hline 1900 & 255 & $\begin{array}{l}298 \text { (of whom } \\
162 \text { in June) }\end{array}$ & 116 & \multirow{14}{*}{$\begin{array}{l}1 \text { honorary } \\
\text { member } \\
1 \text { honorary } \\
\text { member } \\
5 \text { left voluntarily }\end{array}$} \\
\hline 1901 & 185 & 154 & & \\
\hline 1902 & 310 & & & \\
\hline 1903 & 57 & & & \\
\hline 1904 & 88 & 61 & $\begin{array}{l}28 \text { expelled for } \\
\text { nonpayment }\end{array}$ & \\
\hline 1905 & 41 & & 55 expelled & \\
\hline 1906 & & 66 & & \\
\hline 1907 & & & & \\
\hline 1908 & & & & \\
\hline 1909 & & & & \\
\hline 1910 & & & & \\
\hline 1911 & & 1 & & \\
\hline 1912 & & 3 & & \\
\hline 1913 & & 3 & & \\
\hline
\end{tabular}

Source: Folkrörelsearkivet i Blekinge, Acc. 1984/67, Karlskrona Varvsarbetareförbund, Årsberättelser från kassören, I900-I9I3; Marinmusei arkiv, Karlskrona, Protokoll i6/2/06.

with the dockyard authorities at a local level. This could take the form of a written request to the varuschef, and in 1907 it was reported that 747 dockyard workers, most of them not actually members of the association, had signed a petition to the varuschef asking him to change dockyard payday arrangements. ${ }^{26}$ Without the means to reinforce such requests, there was not much that could be done if the varvschef chose to reject it, however, and the absence of any concerted campaigning on wages, hours, or working conditions meant that the association was rather cursorily dismissed by activists two decades later. ${ }^{27}$ However, its minutes do reveal that it was prepared to take up other issues. One of its earliest ventures was the establishment of a mutual sickness benefit fund for members and their

26. Marinmusei arkiv, Karlskrona, Statsanställdas förbund avd 2136 arkiv; serie A I:2, protokollsbok, 1900-I906 [hereafter protokollsbok]. Karlskrona Varvsarbetarnas Förening [hereafter KVAF] minutes, 6 June 1907.

27. The Stockholm activist, C.A. Nyström, claimed in I9I4 that the military restrictions on the day labourers prevented from them indulging in anything which could be described as a "proper" trade union. Cited in Kaj Björk, Försvarsverkens Civila Personals Förbund 1917-1942 (Stockholm, 1943), p. 36. This attitude is also discernible in the union's tenth anniversary history, written by its first chairman. Edoff Andersson, Försvarsverkens Civila Personals Förbund Io år (Stockholm, 1927). 
dependents in I90I, despite the existence of official arrangements which entitled workers to half their wages in the event of absence from work through sickness, and full pay if they were hospitalized or suffered serious injury at work. ${ }^{28}$ Dockyard workers were also entitled to free medical care and drugs under the terms of their employment, but even so it is interesting that it should have been thought necessary to supplement these provisions with a mutual fund. To claim official sick pay, workers had to have written confirmation of their incapacitation from a naval doctor, and the mutual fund was possibly a means of avoiding this constraint. ${ }^{29}$ Whether, in either case, this amounted to an outright rejection of official paternalist structures cannot be stated from the existing evidence, but it does suggest a workforce which was not entirely prepared to be "bought off" by generous state benefits.

From 1913, there was a new seriousness to the dockyard workers' campaigns. A meeting in February I9I 3 resulted in the foundation of a new organization, the Naval Dockyard Workers' Union (Marinens varvsarbetareförbundet, or MVAF), which from the beginning cooperated with workers at the sister dockyard in Stockholm, and soon became a branch of an embryonic national organization with common rules. The KVAF continued to exist as a separate organization for a number of years, but in practice the two organizations were the same, at least in terms of the leading activists, and the formal merger took place almost unnoticed on I January 1916.30 From its foundation, the MVAF began a prolonged campaign for improved wages, spurred on initially by the steep rise in the cost of living as a result of wartime inflation. Workers' incomes were made up of a basic day rate supplemented by a complicated piecerate system, and, on top of this, they could expect to negotiate a war supplement (krigstidstillägg) to offset inflation, and also to earn overtime. Indeed, it was argued that the amount of overtime expected of the workforce undermined the management's argument that there were not sufficient funds for a general pay rise. ${ }^{3 \mathrm{I}}$ The complexity of workers' incomes, as opposed to basic wage rates, means that it is almost impossible to calculate actual incomes for different groups of dockyard workers, and to adjudge

28. KA, Reglemente för Marinen, del I (I9I5) bil., §ı 2:I, a,b. Folkrörelsearkivet i Blekinge [hereafter Folkrörelsearkiv], Acc. I984/67: Karlskrona Varvsarbetareförening, I900-1920. Report of committee set up to inquire into sickness benefit fund, 8 February I90I.

29. British dockyard workers, who also enjoyed some limited official benefits of this kind, seem also to have taken an active part in mutual benefit societies. There were "hundreds" of such clubs and societies at Devonport dockyard in the early twentieth century, the largest of them having approximately 5,000 members in 1904; Hilson, "Working-class Politics in Plymouth", p. 100. 30. Marinmusei arkiv, protokollsbok, 1913-1917. Marinens Varvsarbetarnas Förbund [hereafter MVAF] minutes, i4 March i9is.

31. Marinmusei arkiv, protokollsbok, I913-1917. MVAF minutes, 6 March i915. 
Table 3. MVAF minimum wage proposal for all dockyard workers, November I9I4

\begin{tabular}{lccc}
\hline Workers & Minimum age & Years in service & $\begin{array}{c}\text { Basic pay rate } \\
\text { (per day) }\end{array}$ \\
\hline Craftsmen (yrkesarbetare) & 18 & - & $2 \mathrm{kr} 50$ öre \\
& 21 & 4 & $3 \mathrm{kr} 30$ öre \\
Labourers & 24 & 7 & $3 \mathrm{kr} 70$ öre \\
\hline
\end{tabular}

Source: Folkrörelsearkivet i Blekinge, Acc 1984/6, FCPF and 36, Ankomna skrivelser I913-I925: (copy) Varvschefen to KMF, 24/II/I4

whether they had a grievance or not. ${ }^{32}$ What is more important is the principle of a collectively negotiated settlement which lay behind the proposal. As the matter stood, the basic day rate was set according to the individual contract agreed between the workman and the Crown when the former was taken on, and could be adjusted on the recommendation of a foreman or other supervisor. The union proposed the replacement of these individual tariffs by a collective system which guaranteed a minimum basic rate for all workers in a particular category. The first such proposal, in I9I4, set the pattern for following proposals, and is set out in Table 3 .

In other words, what was at stake was more than merely the material level of wages; it concerned the more fundamental issue of management control of the workforce and the formal relationship between worker and management. The union argued that the existing system was arbitrary and encouraged favouritism, and that relationships outside the yard were as influential as competence at work in forming the judgements of foremen. ${ }^{33}$ The officers in charge of the dockyard departments at Karlskrona were deeply sceptical about the new wage system proposals, arguing that it was vital to the smooth running of the dockyard to retain a system for rewarding merit, and, significantly, the possibility of sanctioning workers

32. In 1917, the union asked that pay packets should contain details of how wages were broken down, in recognition of their complexity. This was refused on grounds that the dockyard lacked the necessary administrative resources; Folkrörelsearkiv, Acc. 1984/67, Försvarsverkens civila personalförbund avd 36, Karlskrona [hereafter FCPF], incoming correspondence 1913-1925, I93 I-1934. Head of Engineering Department to varvschefen, 3 July I917, in response to worker proposal of 16 June.

33. The union submission to the authorities argued that the current system left decisions "in the hands of one or other foreman or supervisor, who with the best will in the world, on many occasions cannot entirely free himself from personal sympathies and antipathies". Cited in Folkrörelsearkiv, FCPF incoming correspondence, heads of department to varvschefen, n.d. (early 1916). All translations from the Swedish are the author's unless otherwise indicated. 
who underperformed. The head of the Engineering Department argued that minimum wages were acceptable only if management retained the right to withhold them from workers who did not do their jobs properly. ${ }^{34}$ The varuschef reported his conclusion to the KMF in I9I4 that, "the system is fundamentally wrong in that wages are not linked to labour productivity, but to other considerations, namely age and length of service, by which the feebly talented and least productive individuals will be favoured". ${ }^{35}$ Particularly striking is the view, expressed by the head of the buildings department, that the increased job security enjoyed by dockyard workers vis-à-vis workers in private industry, meant that a discretionary wage system was an important means of maintaining motivation and productivity..$^{36}$ For what this implies is the identification of problems specific to the management of dockyards as a state-owned industry, problems which were also experienced by dockyard administrators in other countries. In both Britain and France, at this time, steps were taken towards the reorganization of naval shipbuilding on a more commercial basis: new construction was contracted out to private suppliers; dockyard administration was decentralized, and an increasing proportion of the workforce was hired on temporary contracts. ${ }^{37}$

If a minimum wage system would remove an important lever in management's control over the workforce, then even more controversial were the means by which wages should be negotiated. Like their French and British counterparts, Karlskrona dockyard workers remained bitterly opposed to the system of agreeing wages and promotions on an individual, informal basis, and argued vigorously for the adoption of a centralized, formal, collective bargaining system. The union increasingly concentrated its efforts on securing the principle of collective bargaining. Negotiations between union and management would take place at the level of the central naval administration, i.e. the KMF, and thus remove the influence of local dockyard management. The union had made its proposals directly to the KMF in any case from I9I5, through locally elected delegates who travelled to Stockholm and joined their metropolitan colleagues to attend the KMF in person. The local varvschef and his officers were duly invited to respond to the proposals, but this took place via the central administration rather than through local contact between workers and management. Swedish dockyard workers had no formal channels of access to their employers equivalent to the British petitions system, and relied on the cooperation of the KMF to establish a dialogue. The admiral who received

34. Folkrörelsearkiv, FCPF incoming correspondence, head of Engineering Department to varuschefen, 28 July i9i 4 .

35. Ibid., varuschefen to KMF, 24 November 1914 (copy).

36. Ibid., head of Buildings Department to varvschefen, 3 February I9I6 (copy).

37. J.M. Haas, A Management Odyssey: The Royal Dockyards I7I4-1914 (Lanham, MD, 1994);

Reid, "The Third Republic as Manager"; Hilson, "Working-class Politics in Plymouth", p. 47. 
the delegates in the summer of I9I5 made it quite clear that tolerance of a delegation was to be an exception, and not to establish a precedent, and refused to allow the dockyardsmen to attend the discussions of their proposal in person. Labour sources suggest that the workers felt themselves to be fobbed off with promises to put the wage matter to an inquiry, a process which could take many months or even years. ${ }^{3}$

The I9I4 parliamentary decision to free the dockyard workers from the operation of the krigslagar or "war laws", which placed them under military discipline, might have been thought to give a boost to the campaign, but the situation remained far from clear. When the MVAF sought clarification from the authorities in 1916, the response was that although the krigslagar no longer applied to dockyard workers in times of peace, this was not the case during wartime mobilization, and thus the situation was in effect unchanged. 39 The union began tentatively to discuss the possibility of more militant action, and threatened to make inquiries along these lines in a resolution to the authorities in 1916, but the general feeling remained that this was still not a viable option. ${ }^{\circ}$ "This union is not a militant organization", was the view of one member which appeared to sum up the general attitude..$^{\mathrm{I}}$ The grounds for caution were confirmed by the varuschef, who pointed out that, even in peacetime, the relaxation in the law did not allow the possibility of a strike, as workers remained prevented from carrying out such action by their individual contracts which placed them under the naval regulations. If dockyard workers wished to pursue strike action, their only lawful possibility was to resign and work out their contractual notice before withholding their labour; otherwise they were subject to a disciplinary hearing in a military court. ${ }^{42}$ Nevertheless, despite these restrictions on the available tactics, the MVAF gained confidence from the wider developments within Swedish industry at this time. A resolution from I9I7 stated boldly that, "The right of workers to be consulted is of course a generally acknowledged fact in private industry, and is therefore an essential condition for peaceful labour relations in the royal dockyards." 43 From 1913, a government inquiry had been investigating collective bargaining structures for state-run industry; the argument was however that this should apply only to state "business" (affärsdrivande verk) and not to the dockyards. Dockyard management resisted comparisons with private industry, however, and argued that whilst they had nothing against hearing workers' views, they were under

38. Kungliga Biblioteket, Stockholm [hereafter KB], Blekinge Folkblad, 2 I June 1915.

39. Marinmusei arkiv, protokollsbok, 1913-1917; MVAF minutes, 6 March I916.

40. Ibid., MVAF minutes, I6 March 1916, and I6 October 1916.

41. Ibid., MVAF minutes, I6 October I916.

42. Folkrörelsearkiv, FCPF incoming correspondence, varvschefen to KMF, 3 I March I916 (copy).

43. Marinmusei arkiv, protokollsbok, 1913-1917; MVAF minutes, 29 March 1917. 
no formal obligation to take these into account when deciding wages or any other matters of work conditions.

By I917, it seemed that the management position could no longer be sustained, and the first collective minimum wage agreement, covering all dockyard workers in Stockholm and Karlskrona, came into force on I September 1917. It is not clear what brought about the change of heart on the part of the authorities: possibly they were motivated by the tightening labour market and the fear of losing key workers at a time of increased intensity in dockyard work. There is no evidence to suggest that they reacted in response to the increased social unrest developing in Karlskrona, and in Sweden as a whole, but this undoubtedly boosted the confidence of the labour organizations. Some concessions were also made regarding the union's other campaign goal, the right to negotiation. Under a new system, dockyard workers were entitled to elect delegates, one for every 200 workers elected during working hours, to represent them in negotiations with the authorities on wages and other aspects of working conditions. ${ }^{44}$ The system was designed to ignore the existence of the MVAF, but in practice the union exercised control over the election process, by running its own internal elections before those officially organized in working hours by the dockyard authorities. ${ }^{45}$ The union's main goal was now to secure its recognition as a partner in the wage bargaining process, the socalled right of negotiation or förhandlingsrätt. By the early I920s, the dockyard workers had succeeded in discrediting the delegation system by voting with their feet and simply not participating, and förbandlingsrätt was eventually conceded in $1922 .{ }^{46}$

\section{THE DEVELOPMENT OF A COMMON DEFENCE UNION}

In presenting its demands for a collective wage settlement the MVAF made a distinction between apprenticed craftsmen (yrkesmän) and ordinary labourers. Whereas British dockyard workers invariably petitioned on the basis of trade, and frequently campaigned to maintain existing wage differentials and hierarchies between trades, there appears to be a notable

44. KA, Karlskrona Örlogsvarv [hereafter KÖV], Varvschefens kansli, serie F VII b, Handlingar ang. arbetares löner, vol. I: Kungl. Maj:t to KMF, I6 May г 9 I7 (copy).

45. Marinmusei arkiv, protokollsbok, I917-I919; MVAF minutes, 4 January I91 8.

46. Arbetarrörelsens Arkiv och Bibliotek, Stockholm [hereafter ARAB], FCPF Medlemsbladet, March 1922; Folkrörelsearkiv, FCPF outgoing correspondence, Karlskrona branch to King, 25 August I 92 I. In November I 92 I, the Karlskrona branch voted not to take part in the system any longer; see Thorvald Pettersson, Historik över Försvarsverkens Civila Personals Förbunds avdelning 36 verksambet under den förflutna Is:års perioden, samt en överblick av det organisatoriska arbetet inom varvsarbetarekären för tiden 1900-I92 I (Karlskrona, I936), p. I I. 


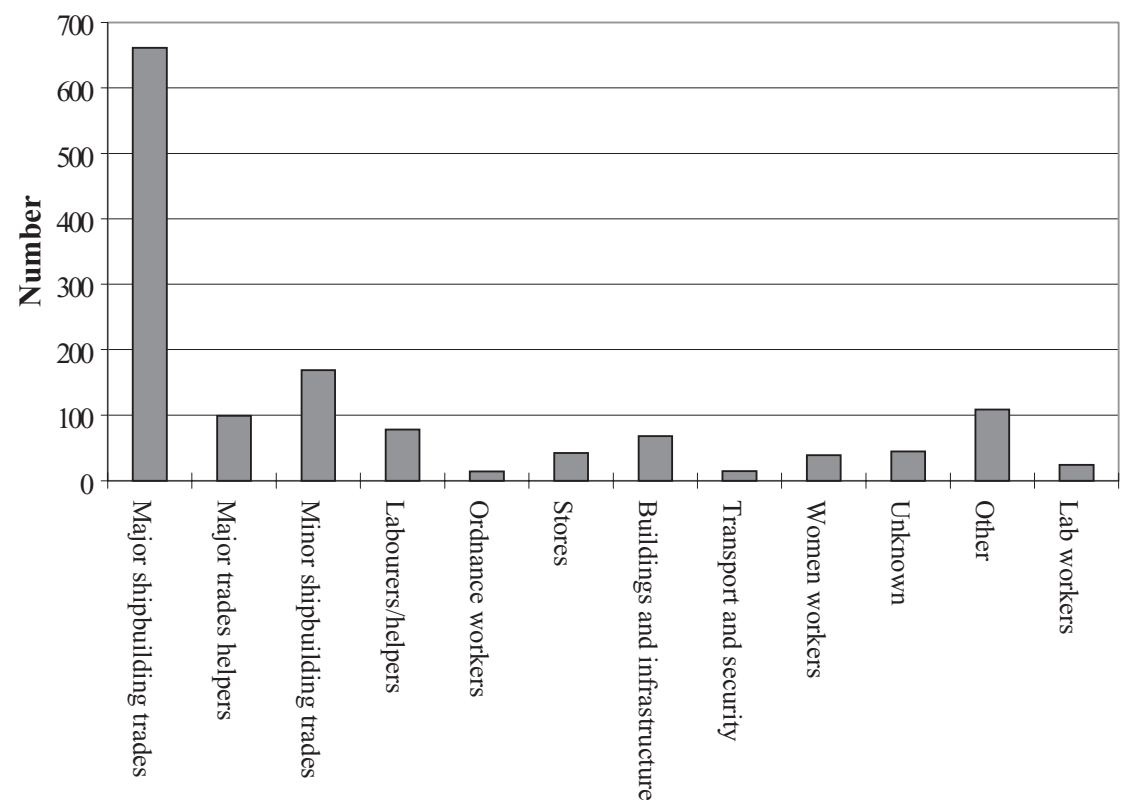

Trade

Figure 3. Members of Karlskrona MVAF, by trade, I917

Source: Marinmusei arkiv, Karlskrona, Statsanställdas förbund avd. 2 I 36, Medlemsmatrikel Serie Era:2 (1913-1918).

absence of sectional rivalries amongst the Karlskrona workers. ${ }^{47}$ The MVAF, and indeed its predecessor the KVAF, embraced all dockyard workers, including those who were not attached to a shipbuilding trade. The membership of the union by trade in I9I7 is illustrated in Figure 3 .

The largest trade group within the union was the platers, but even so these formed only just over 17 per cent of the total membership. Altogether, not quite half (48.5 per cent) of the membership was made up of what may be distinguished as the major shipbuilding trades; the rest included helpers (bantlangare) and representatives of the minor trades, together with many workers not employed in shipbuilding work at all. This last group included workers concerned with maintaining the buildings and infrastructure of the yard, storemen and transport workers, dockyard guards, unskilled labourers, and a small group of women workers employed in the sail and colour lofts.

47. For British dockyard trade unionism, see Galliver, "Trade Unionism in Portsmouth Dockyard". Trade union organization was hindered in the dockyards because of a long-running dispute between the Boilermakers' Union and the ASS (Associated Shipwrights' Society) over the demarcation of their work. 


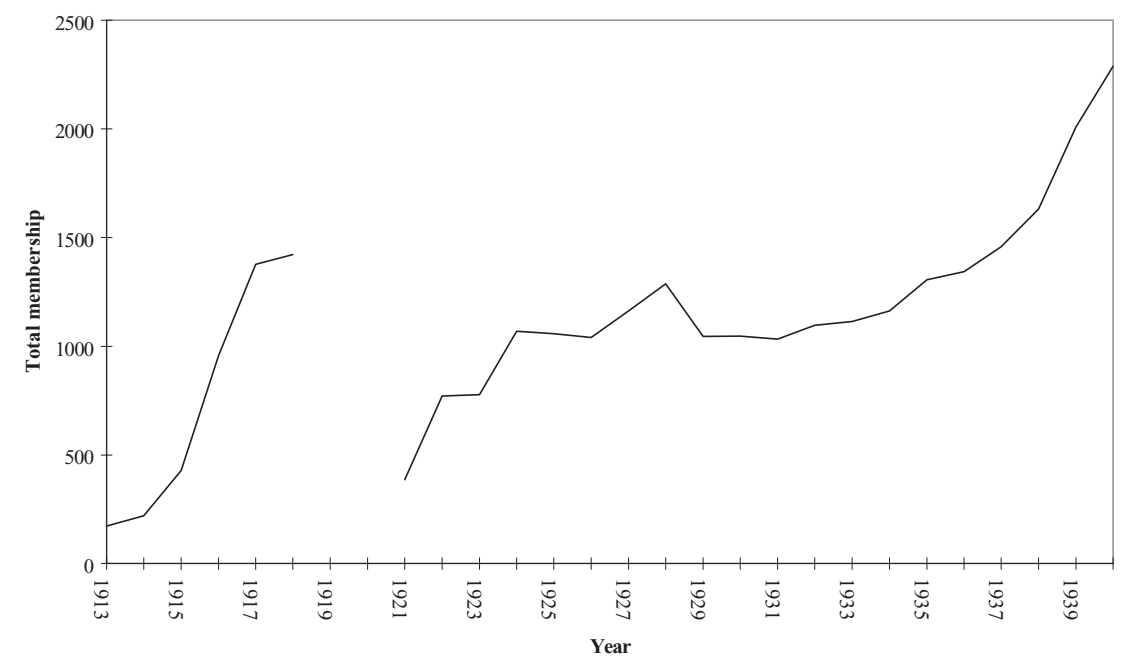

Figure 4. Membership of MVAF I9I3-I918, and Karlskrona branch of FCPF I92 I-I940 Source: Marinmusei arkiv, Karlskrona, Statsanställdas förbund avd. 2 I 36, Medlemsmatrikel Serie Eıa:2 (I9I3-19I8). Arbetarrörelsens arkiv och bibliotek, FCPF Verksamhetsberättelser I92 II940.

Meanwhile, attempts to organize civilian workers employed in other branches of the defence industry resulted in the formation of the Civilian Army Employees' Union (Arméns civila personals förbund or ACPF). $4^{8}$ Three delegates from the MVAF attended the ACPF's founding conference in Stockholm in December 1917, and the two organizations cooperated fairly closely during the following years. Among early campaigning successes may be noted the achievement of the statutory eight-hour day for all civilian defence industry workers, the first group in the country to achieve this goal. The ACPF's I920 congress took up the issue of the unification of the ACPF with the MVAF, and from I January I92 I naval workers from Stockholm and Vaxholm joined their colleagues in the renamed Civilian Defence Employees' Union (Försvarsverkens Civila Personals Förbund or FCPF). The Karlskrona workers were more reticent, but duly affiliated six months later, following a visit from the union's chairman Edoff Andersson. ${ }^{49}$ Figure 4 illustrates union membership after the foundation of the MVAF in I9I3.

The FCP Förbund, of which Karlskrona dockyard workers made up Branch 36, appears to conform to the conventional model of a Swedish trade federation: national in scope, highly centralized, and tightly 


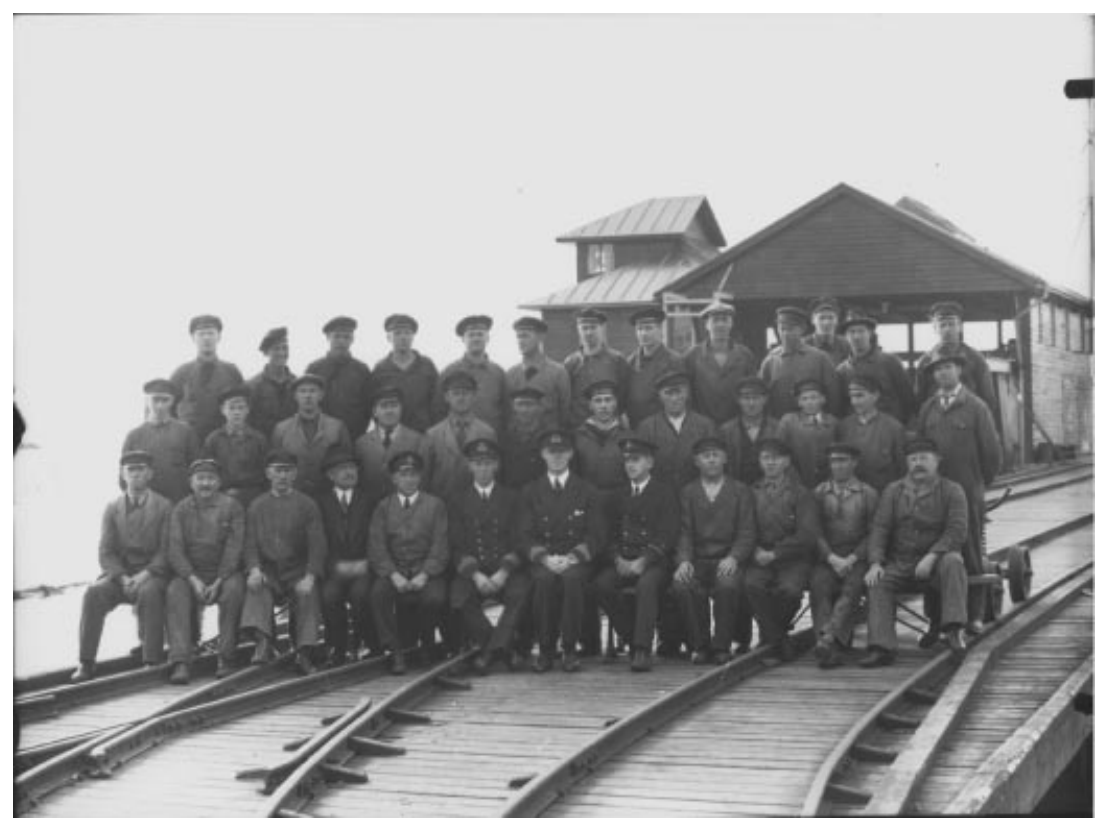

Figure 5. Workers in the Torpedo Department, Karlskrona dockyard, 1930. The torpedo workers formed their own independent workshop club in 1915, but their application for affiliation with the MVAF was rejected. Note the presence of both civilian and naval workers, distinguished by their caps.

Karlskrona Marinmuseums bildarkiv, Karlskrona varvets fotograf

controlled by its Stockholm-based executive committee. The autonomy of the branch was restricted, and local activity was to be confined to negotiating everyday working conditions: the ventilation of a particular workshop, or the provision of overalls and tools for a specific group of workers. Other activities were discouraged, and in I9I7 the MVAF's Stockholm-based chairman, C.A. Nyström, wrote to his Karlskrona colleagues to warn them that wage negotiation with the local dockyard authorities at a branch level was not likely to gain a result. ${ }^{\circ}$ Furthermore, attempts to organize outside the auspices of the MVAF, or later the FCPF, were barely tolerated, as indicated by the rejection of affiliate status for the torpedo workshop club in 1915..$^{11}$ As the FCPF grew in size during the I920s, attempts were made to form workshop-based sections, primarily

50. Folkrörelsearkiv, FCPF incoming correspondence, Nyström (Stockholm) to Karlskrona branch, 8 April i9ı7.

51. Marinmusei arkiv, Statsanställdas Förbund avd 2136, Karlskrona. Serie A I:2, Torped departementets verkstadsklubb protokollsbok, I91 5-1920. 
designed to make the collection of membership fees easier, and thus reduce the burden of work on committee members. ${ }^{22}$

Even so, the FCPF's supremacy in the dockyard did not go entirely unchallenged. Branch 96 of the Swedish Metal Industry Workers' Union (Svenska Metallindustriarbetareförbundet) was founded in Karlskrona in I90I, and gained a great boost from 1907, when it succeeded in organizing several hundred dockyard workers. ${ }^{3}$ Like most local branches, the union had rather a chequered history during its early years, but it managed to retain its foothold in the dockyard even after the formation of the MVAF. As late as 1929, the branch retained 4I members in Karlskrona, most of them working in the engine workshop. ${ }^{54}$ This number was insignificant compared to the I,000 or so in the MVAF, but it was enough to fuel a longrunning dispute between the two unions over representation of the dockyard workers in the bargaining process. With members in other branches of the defence industry, Metall was able to block FCPF affiliation to the central trade union organization, LO, for a number of years.

In its conflict with the Metalworkers' Union, which drew a fair proportion of its membership from the shipbuilding workers of Göteborg and Malmö, the MVAF, and later the FCPF, were also resisting attempts to draw comparisons between its own members and a wider community of shipbuilders. This was despite the efforts of management to do just this, and also some evidence to suggest that Karlskrona workers were to some extent part of a common shipbuilding labour market, and could, if necessary, migrate to other shipbuilding areas such as the new Öresund shipyard in Landskrona.55 Indeed, it is doubtful the extent to which there existed an occupational identity based on shipbuilding as such in Sweden, comparable with the skilled trades associated with the British industry. According to Svensson, the rise of Swedish shipbuilding may be seen as a challenge to the British reliance on skilled craftsmanship; Swedish firms were less labour intensive and placed a far greater reliance on technical investment and formal supervisory structures. ${ }^{6}$ Most of the research on Swedish shipyard workers has focused on the major commercial shipyards of Gothenburg and Malmö, where shipbuilding had notably not become a specialism for the local heavy engineering firms by the end of the

52. ARAB, FCPF Medlemsbladet, November 1925.

53. Svenska Metallindustriarbetareförbundet, avdelning 96 i Karlskrona: "En Jubileumsskrift" (Karlskrona, 1976).

54. Folkrörelsearkiv, Acc. I984/67, FCPF outgoing correspondence. Report on branch membership, I4 February i929.

55. Magnus Wikdahl, Varvets tid: Arbetarliv och kulturell förändring $i$ en skeppsbyggarstad (Stockholm, 1992).

56. Thommy Svensson, Frän ackord till månadslön: En studie av lönepolitiken, fackföreningarna och rationaliseringarna inom svensk varvsindustri under 1900-talet (Göteborg, 1983). 
nineteenth century. ${ }^{57}$ This did not apply to Karlskrona, of course, where shipbuilding had been carried out for several hundred years, but it is interesting that, despite this, Karlskrona workers were still inclined to identify themselves as state employees rather than members of a particular trade.

Indeed, evidence suggests that the union was becoming increasingly concerned to align itself not only with the wider community of defence workers but also with state employees in general. A Karlskrona branch meeting in I916 voted unanimously for full cooperation with the Civil Servants' Cooperative Organization (Statstjänarnas samorganisation) in Karlskrona, to lobby for wartime wage supplements. ${ }^{8}$ During the years immediately following the war, this cooperation was extended to national campaigns for pensions and holidays. At its meeting in October I9I 8, the Karlskrona branch voted to affiliate formally to the organization, and in doing so aligned itself with the interests of the state railwaymen, postmen, customs workers, prison warders, and telecommunications workers, both male and female. ${ }^{9}$ The loose cooperative federation which developed during and immediately after the war was the forerunner of the Civil Servants' Union, Stadstjänares Centralorganisationen, or SCO, founded in I 923.

The success of the MVAF, and its successor the FCPF, relied on the union's ability to create a common identity among its members which stretched across the dockyard trades, and following the foundation of the FCPF, across the entire defence industry. The members' newsletter, which was produced on two occasions in I9I9 and monthly from 1920, was concerned to cement this collective identity, as was the official tenth anniversary history of the union authored by its first chairman Edoff Andersson. In his account, Andersson dismissed earlier attempts to organize defence industry workers, including the local KVAF, as not really significant, and also stressed the failure of other unions, such as the Metalworkers' Union, to make any significant headway in organizing in the dockyards or the army workshops. According to Andersson, the founding of the MVAF, itself a "very primitive" organization compared to the FCPF, came as a breakthrough from the initiative of Stockholm workers in 1914 , ignoring any continuity from the KVAF. ${ }^{60}$ In an editorial article in the members' newsletter, written two years previously, Andersson had condemned the existence of "local patriotism" within the

57. Lars Berggren, Angvisslans och brickornas värld: $\mathrm{Om}$ arbete och facklig organisering vid Kockums Mekaniska Verkstad och Carl Lunds fabrik i Malmö I 840-1905 (Malmö, I991); Stråth, Varvsarbetare $i$ två varvstäder; Svensson, Från ackord till månadslön.

58. Marinmusei arkiv, protokollsbok, 1913-1917; MVAF minutes, 8 September I916.

59. Ibid., I2 October 1918; I3 September 1919.

60. Andersson, Försvarsverkens Civila Personals Förbund, p. I . Björk, Försvarsverkens Civila Personals Förbund, also attributes the first initiative to found a dockyard union to the Stockholm workers only. 
trade union movement, which meant that, through their misplaced loyalty to their local branches, members were apt to misunderstand the wider implications of the federation and the movement. ${ }^{6 \mathrm{I}}$

By the I920s, the national federation had indeed become well-established as an organizational form within the Swedish labour movement, following the formation of the first fackförbund among the typographical workers in I 886. Yet, as Göran Salmonsson has pointed out, we should be wary of a teleological view of Swedish labour history which tends to take the existence of the fackförbund for granted. ${ }^{62}$ Different forms of labour protest, whether localized, spontaneous, or even violent, are seen as a phase in the transition towards modern trade unionism, where wellorganized campaigns to secure collective bargaining are central. ${ }^{63}$ Echoing Edoff Andersson's comments cited above, Lars Berggren's study of shipyard and other metalworkers in Malmö describes how workers gradually adopted a "modern" consciousness of the need for collective discipline, which led them to reject older forms of protest, such as St Monday, initiation rites and drinking rituals. ${ }^{64}$ Salmonsson's own account of the formative years of the Metalworkers' Federation is a careful exploration of how the federated form gradually came to prevail over other models of trade union organization. Reflecting recent work in social history, it is possible to see this as a dynamic process by which the union moulded the identities of its members, rather than itself being a reflection of any material realities. ${ }^{65}$ Work itself, and disputes over the actual process of work itself, were not the driving forces behind the development of the union so much as events outside the dockyard. Workers' consciousness of what was just and unjust about their working conditions, and how these ought to be remedied, were channelled through the union's interpretation of these circumstances, rather than rising spontaneously from local workplace conditions.

\section{FORCES AGAINST CENTRALIZATION: THE LOCAL LABOUR MOVEMENT IN KARLSKRONA}

The official story of the development of trade unionism within the defence industry identified a growing consciousness among defence industry

6r. ARAB, FCPF Medlemsbladet, October 1925.

62. Göran Salmonsson, Den förståndiga viljan: Svenska Järn och metallarbetareförbundet I888-1902 (Uppsala, I998).

63. Ingemar Johansson, Strejken som vapen: fackföreningar och strejker i Norrköping I870I9I0 (Stockholm, 1982)

64. Berggren, Angvisslans och brickornas värld.

65. Salmonsson, Den förståndiga viljan. See also Eva Blomberg, Män i mörker: Arbetsgivare, reformister och syndikalister: Politik och identitet i svensk gruvindustri 1910-1940 (Stockholm, 1995). 
workers of their status and common interest as state employees, and as we have seen, it was this version which was disseminated through the pages of the membership newsletter during the 1920 . ${ }^{66}$ Furthermore, the insistence that the union was concerned strictly with trade issues meant that no mention was made in official quarters about the links between the union and other groups within the organized labour movement, including political organizations. Yet inevitably the dockyard trade unions developed against the wider background of the local labour movement. Karlskrona Arbetarekommun, or workers' council, was founded in I 896, drawing most of its support from local trade unions outside the dockyard, and contesting municipal elections from the turn of the century. As elsewhere in Sweden, the labour movement in Karlskrona suffered a major setback following the general strike in I909. The dockyard workers did not participate in the strike, but their organization experienced the same blow to morale as other unions. Membership of the kommun contracted sharply, and it was forced to cancel even its social events because of a lack of funds. Apart from the strike, the KVAF cooperated generally with the kommun, participating in the annual May Day demonstration, and helping with municipal election campaigning, although it does not appear that there was any formal affiliation. The important point is that the relaunch of the MVAF, and its subsequent growth in membership and confidence coincided with renewed vigour within the local labour movement. Something of an electoral breakthrough was achieved following the suffrage reform of I9II, when, despite falling membership, the kommun succeeded in getting its candidates, Oskar Kloo and J.A. Ingvarsson, elected to the second chamber of parliament. There was also a renewed vigour in municipal campaigning; the kommun ran its own electoral list as the Labour Party, and, from I9I3, was able to hear reports from its own group of representatives on the local council. ${ }^{67}$

The increased publicity attached to the wage negotiations undoubtedly played its part in recruiting members to the new MVAF, as did also the tightening labour market in the context of war. The order to mobilize the dockyard in response to the war prevented workers from resigning, and thus, paradoxically, tighter restrictions may have strengthened the assertiveness of the workforce. Dockyard workers who did leave the yard also had more chance of gaining shipbuilding employment elsewhere, and a number of Karlskrona workers joined the workforce at the new Öresund shipyard at Landskrona. ${ }^{68}$ Yet it was events outside the dockyard which had the greatest impact. From 1916, local politics was increasingly 
dominated by the growing concerns over food shortages, and attempts to organize local rationing schemes for basic items such as bread and potatoes. The Arbetarekommun acted as a coordinating body for a number of local organizations interested in consumer issues, including the MVAF. Furthermore, in its campaigns against the shortages, the kommun had found an increasingly political voice, demonstrating a new willingness to make ideological proclamations. The strength of this voice was sharpened both by the deepening split within the Swedish labour movement, and from early in I 917 by events in Russia. ${ }^{69}$ The call to demonstrate on I May I917 referred to "society shaking to the foundations as never before"..$^{\circ}$ However, the organizers of the May Day demonstration were overtaken by events, when, during the evening of 26 April, between 5,000 and 6,000 people gathered in central Karlskrona. The instigators were off-duty sailors, soldiers, and conscripts, who had assembled in protest against the declining quality of their rations. Local labour leaders persuaded most of the crowd to disperse once the commanding admiral had promised to take up the issue, but it was obviously a tense moment, and in the aftermath some damage to property occurred. Events were followed by another demonstration the following Saturday, when the 5,000 people reported to be present sent both a petition and a delegation into the town hall to discuss the local organization of rationing. When it finally came, the I May demonstration was thought to be the largest ever, with 8,000 taking part. ${ }^{7 \mathrm{I}}$

The dockyard workers participated en masse in these events. The local labour newspaper, Blekinge Folkblad, reported that as good as the whole workforce were assembled behind the MVAF banner on I May, and at the food demonstration, three days earlier, they turned up directly from work..$^{2}$ The MVAF membership books reveal the impact these events had on the organization: 217 new members signed up during the month of May alone, compared with 96 during June and only 34 in April. ${ }^{73}$ It seems therefore that events outside the workplace were a direct cause of the increased interest in dockyard organization, rather than anything which was taking place inside the workplace, or indeed campaigns in which the MVAF was particularly involved. The wage campaign continued throughout I9I6 and I9I7, although energies were diverted away from securing a rise in the basic level of wages, into seeking instead a war supplement which would take high consumer prices into account. The yard was fully stretched, and overtime was also an important issue. However, during the winter of 1916-1917 at least, the crucial battleground was consumption

69. Carl Göran Andræ, Revolt eller reform: Sverige inför revolutionerna i Europa 1917-1918 (Stockholm, 1998).

70. KB, Blekinge Folkblad, 2 April 1917.

71. Ibid., 3 May 1917.

72. Ibid., 28 April 1917.

73. Marinmusei arkiv, FCPF medlemsmatrikel, I917. 
issues rather than production. The MVAF negotiated itself with the municipal provisions committee (livsmedelsnämnden), and also with the dockyard authorities, to try to secure access to the naval supplies of basic foodstuffs for dockyard employees. ${ }^{74}$

It is also necessary to consider to what extent a franchise factor may have been influential on union activity. The partial extension of the franchise in I9I I, and the election of two social democratic parliamentary representatives (riksdagsmän) for Blekinge awakened interest in the possibilities of using the riksdag, the Swedish parliament, as a source of redress. One riksdagsman in particular, J.A. Ingvarsson, took his role as Blekinge representative very seriously, and was active not only in the wage campaign, but also in lobbying for dockyardsmen's pensions and cost of living wage supplements. Ingvarsson used his position to table motions, ask parliamentary questions, and set up meetings between the union and the KMF or naval minister. Through Ingvarsson, other Blekinge riksdagsmän also came to be involved: it was reported for example that three Blekinge colleagues had seen the naval minister to forward the dockyard wage proposals in 1914. ${ }^{75}$ At its meeting in July i915, the Karlskrona MVAF formally recorded its thanks to the riksdagsmän for their help. ${ }^{76}$

Over the space of just a few years, therefore, the role of local riksdagsmän in dockyard affairs was defined. By the time of the second chamber election in I917, the dockyard had become an electoral issue. The social democratic candidate W. Karlsson made his electoral address to MVAF members, and promised that he would use his influence as best he could for dockyard affairs. ${ }^{77}$ A printed address from the social democrats, running as the Arbetareparti or Labour Party, appealed explicitly to the dockyardsmen's interests: "If your wish is that the particular dockyard issues, which may be dealt with by the parliament, should be settled favourably, then it is absolutely necessary that you use your vote in order to secure strong representation for the labour party." 78 The extension of the franchise meant that the dockyard workers accounted for a not insignificant proportion of the Karlskrona electorate, and one which candidates could not afford to ignore. This identification of the dockyard workers as a constituency with distinct political interests was a process which was confined to Karlskrona, however. It was the Blekinge riksdagsmän who took up the dockyard issues on behalf of all dockyard workers in Stockholm as well as Karlskrona. There is no evidence of any involvement on the part of Stockholm parliamentarians. Although the

74. Ibid., protokollsbok, I913-I917; MVAF minutes, is December I917.

75. Ibid., MVAF minutes, 8 October I9I4.

76. Ibid., MVAF minutes, i9 July i9i 5 .

77. Ibid., MVAF minutes, Io August I917.

78. Folkrörelsearkiv, acc. 1984/67, KVAF: Upprop till varvets arbetare, I917. 
social democrat, Ingvarsson, was the most active, the campaign could also draw in other local representatives of different party persuasions. Two points may be made here. In the first place it seems that apart from political lobbying, the most important role of the riksdagsman was to act as a local contact in Stockholm. Karlskrona was remote from the metropolis, and some of the correspondence between Ingvarsson and the MVAF suggests that the former had an important role to play in forwarding information, for example concerning the passage of dockyard related legislation through the riksdag.

Secondly, it seems that Ingvarsson and the other Blekinge riksdagsmän were acting not only in support of the interests of the dockyard workers, but also in the interests of the town of Karlskrona as a whole. The scalingdown of naval expenditure and the uncertainties over the dockyard's future awakened local awareness of just how intimate the links were between Karlskrona's prosperity and the presence of the dockyard. Not only the local parliamentary representatives, but also the mayor of Karlskrona was active in lobbying the KMF.79 Ingvarsson himself also played a prominent role in the official inquiries into the dockyard's future, and was a strong advocate of turning over the dockyard to civilian uses. ${ }^{80}$ This was also taken up by the local council, which established a special committee to look into civilian solutions to the problem of underemployment of the dockyard resources. ${ }^{81}$ Isolation from other centres of industry and complete dependence on the dockyard was a feature Karlskrona shared with many other European dockyard towns, hardly surprising given that the choice of the town's location was based on the strategic requirements of the late seventeenth century. In this respect, the outlook of the Stockholm dockyard workers differed substantially from that of their Karlskrona comrades, as did the attitudes of the metropolitanbased FCPF leadership.

\section{CONCLUSION}

The growing body of research on the British dockyards points towards a number of common features distinguishing the dockyard towns. These include: the continuity of organization in workplaces which have existed

79. Ibid., FCPF incoming correspondence, Ingvarsson to Dahlström, 30 January I9I 5 .

80. Gäfvert, "Kontinuitet i föränderlig omvärld".

$8 \mathrm{I}$. In the words of the motion to establish the committee: "it is generally known that the interests of Karlskrona are intimately connected to the state of the royal dockyard. It has already been shown in the town council to what extent the town's economy is dependent on retaining the dockyard in its entirety". Karlskrona kommunarkiv: Kommittéen utsedd att följa Örlogsvarvets verksamhet; Serie A I: I Protokoll med handlingar, I919-1920, stadsfullmäktige meeting, I9 July I919, § I3. 
since the seventeenth century or earlier, and could claim to be some of the earliest large-scale industrial organizations; the importance of strategic and political considerations in decisions affecting production; locations which were often isolated from other centres of industry; and the existence of particular methods of labour organization, which gave rise in turn to peculiar forms of industrial relations and labour politics. Taken together, these factors suggest that dockyards need to be considered in their own right, and not merely as part of the wider shipbuilding industry. For one thing, the dockyards were sheltered from the fluctuations of the business cycle which notoriously beset private shipbuilding, and were thought to dictate particular worker cultures and labour strategies. ${ }^{82}$ Furthermore, dockyard towns were frequently isolated from the major industrial and engineering centres, and therefore lacked the common and extensive shipbuilding labour markets similar to those existing in Göteborg or on Tyneside. Whilst this tied many dockyard workers in a position of dependency on the dockyard, it also meant that labour was not always readily available in times of rapid expansion, and the position of the workforce was thereby strengthened.

Whilst there is definitely a case for considering dockyards as a distinct industry, it is however necessary to retain a shipbuilding perspective. The peculiar features of shipbuilding, notably its capital intensity and long production runs, were as inescapable in dockyards as they were in private shipyards. Dockyard administrators, similarly to their counterparts in private shipyards, were faced with the need to retain a core group of skilled workers even when work was slack, and were thus obliged to take measures designed to induce a long-standing culture of loyalty among sections of the workforce. Furthermore, the differences in labour organization in the British and Swedish dockyards also mirror the differences in the shipbuilding industry as a whole, notably the British obsession with skill, and the flatter hierarchies of the Swedish industry. The development of trade unionism in Karlskrona is more closely linked to a general Swedish model of the general industry (as opposed to a skillbased) union than to any international dockyards model. Indeed, Karlskrona workers showed a far greater capacity to identify themselves as dockyard workers, as defence industry workers and, most significantly, as employees of the state, than their counterparts in the British dockyards.

Despite the best efforts of the union leadership to centralize the dockyard union around the collective interests of its members as defence industry employees, the dockyard workforce in Karlskrona cannot be considered in isolation from the wider developments within the town.

82. For the Swedish shipbuilding industry see Svensson, Från ackord till månadslön, and Stråth, Varvsarbetare $i$ två varvstäder. For the British shipbuilding industry, see Sidney Pollard and Paul Robertson, The British Shipbuilding Industry, I870-1914 (Cambridge, MA, 1979). 


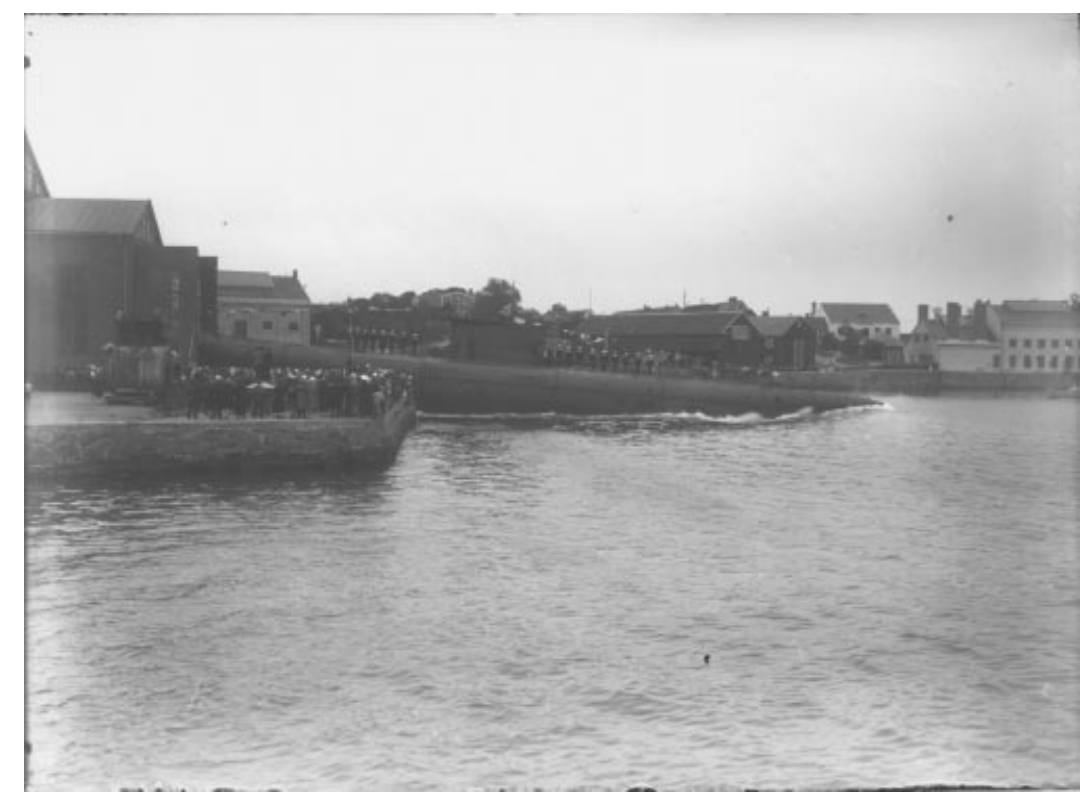

Figure 6. Launch of the submarine Gripen, 1928. Ship launches were important public spectacles for the commemoration of the work of the dockyard.

Karlskrona Marinmuseums bildarkiv, Karlskrona varvets fotograf

Indeed Karlskrona was probably typical of dockyard towns, in its geographical isolation from other industrial centres, and its deep dependence on the dockyard. On the surface, Karlskrona, and indeed other dockyard towns, did not conform to the model of a company town, in that the naval authorities made little attempt to intervene in civilian affairs. This is most clearly seen in the lack of paternalist provisions such as "company" housing and the like. ${ }^{8}$ On the other hand, in most cases, and here Karlskrona was no exception, dockyards were located in the heart of an extensive naval infrastructure. Dockyard towns were essentially military towns: Karlskrona had been the main base of the Swedish navy since the late seventeenth century, and militarism permeated all aspects of the town's life. Inevitably there was always a large presence of military and naval personnel stationed in the town or waiting to join their ships. It has not been possible to consider the wider culture of the dockyard town in

83. Peter Hilditch, "The Dockyard in the Local Economy", in M. Duffy et al. (eds), The New Maritime History of Devon, vol. 2 (London, 1994) compared the lack of company provision in Plymouth with the shipbuilding company town of Jarrow in northeast England. For the paternalism of shipbuilding firms in Sweden, see Stråth, Varvsarbetare $i$ två varvstäder, and Wikdahl, Varvets tid. 
this article, but it undoubtedly raises interesting questions. Just as it cannot be taken for granted that the dockyard workforce was bought into submission and quiescence by a combination of military oppression and generous benefits, nor can it be assumed that the population as a whole was susceptible to attitudes governed by loyalism and patriotism, based on support for the navy. We need to look more carefully at exactly how the presence of the navy was represented and experienced in the town, and at the impact of both formal and informal celebrations of naval patriotism. ${ }^{84}$ By the turn of the century dockyard shiplaunches had become public spectacles in Karlskrona as they had in Britain, but what role did these play in comparison to the launch of a British Dreadnought, given the very different naval ambitions of the Swedish state? ${ }^{85}$ What was the response of the local labour movement, actively involved in an antidefence campaign before the First World War, to navalism in Karlskrona? An exploration of such issues would greatly enrich our understanding of the Swedish labour movement, and of popular politics in general.

84. Lunn, "Labour Culture in Dockyard Towns"; K. Lunn and A. Thomas, "Naval Imperialism in Portsmouth, I905-1914", Southern History, io (1988), pp. I43-I 59.

85. For British dockyard shiplaunches see Hilson, "Working-class politics in Plymouth", ch. 5. 